\title{
Synergistic Effects of Nutrients and Lead on the Quantitative Ultrastructure of Cyclotella (Bacillariophyceae)
}

\author{
L. Sicko-Goad, B. G. Ladewski, and D. Lazinsky \\ Great Lakes Research Division. The Institute of Science and Technology. The University of Michigan, Ann Arbor. Michigan 48109
}

\begin{abstract}
A four-way completely crossed factorial enrichment experiment $(2 \mathrm{~T} \times 2 \mathrm{Si} \times 2 \mathrm{~Pb} \times 2 \mathrm{P})$ was used to analyze the short ( $2 \mathrm{hr}$ ) and long ( $48 \mathrm{hr}$ ) term effects of nutrients and lead on the quantitative ultrastructure of Cyclotella, a diatom. Some of the cytological modifications that have been reported to occur in other algae as a result of heavy metal exposure occurred in Cyclotella, but were mediated in some cases by the addition of low levels of nutrients. While it is extremely difficult to simulate the natural environment where a variety of parameters may be changing simultaneously, it is suggested that factorial design experiments approximate it more closely. Furthermore, environmental factors that may change the availability of metals may also change the physiological state of the cells, which may also either amplify or mitigate the metal effects.
\end{abstract}

Quantitative electron microscopy has been utilized successfully to determine the intracellular effects of heavy metals on phytoplankton (Sicko-Goad and Stoermer 1979; Sicko-Goad 1982; Rachlin et al. $1982,1984)$. The method is especially powerful when used with natural phytoplankton assemblages, because it facilitates the determination of species-specific effects at very low concentrations in the mixed assemblage which may consist of several hundred algal species. Although the technique may be limited by the ability to successfully distinguish individual species in thin section by distinctive cytological or cell wall features (Sicko-Goad 1982), it does allow assessment of stress effects on single species in the natural environment.

A variety of environmental parameters as well as physiological conditions are known to either mitigate or amplify the effects of metals on phytoplankton. For example, $\mathrm{pH}$, temperature, the presence of chelators or concentration of nutrients may affect metal toxicity by reducing free ion activity of metals (e.g., Rabsch and Elbrächter 1980; Thomas et al. 1980b; Gipps and Coller 1980, 1982: Canterford and Canterford 1980; Hallas et al. 1982; Crist et al. 1981; Ahlf et al. 1980; Harding and Whitton 1977; Allen et al. 1980: Davies 1978; Gadd and Griffiths 1978). Similarly, these environmental conditions may also affect the physiological responses of the plankton by producing growth conditions which are non-optimal and it is reasonable to suspect that the recent past growth history of the cell as well as life cycle stage may also play an important role in the expression of metal effects.

Lead toxicity effects may be related to phosphate nutrient status. Koeppe and Miller (1970) demonstrated that in maize mitochondria, the addition of lead followed by the addition of phosphate resulted in fewer enzymatic inhibitions than produced by lead alone, presumably the result of lead phosphate precipitation. Monahan (1973) found that cells of a green alga that were phosphate sufficient were less susceptible to lead than cells which had no stored phosphate. Similar results have been reported by Sicko-Goad and Stoermer (1979), who found that lead was incorporated in polyphosphate bodies. Studies of metal incorporation into polyphosphate bodies have been elaborated by Jensen and his coworkers (Jensen et al. 1982; Baxter and Jensen 1980a, 1980b; Rachlin et al. 1984) who found that a variety of metals could be incorporated into polyphosphate and consequently be removed from active metabolic processes.

The importance of the synergistic effects of nu- 
trient sufficiency in mitigating toxic metal effects has not been studied extensively. In the Laurentian Great Lakes, the two nutrients which most commonly limit diatom growth are phosphorus and silica. In order to understand the synergistic effects of nutrient availability on metal toxicity, experiments were conducted in which a natural phytoplankton assemblage was exposed to low level doses of lead over a period of 48 hours. The assemblage was spiked with phosphate and silica to levels which are optimal for growth in the lake and then exposed to lead. The quantitative ultrastructural effects of both the nutrients and the metal lead on the naturally occurring diatom Cyclotella sp. are presented in this paper.

\section{Materials and Methods}

Nearshore water of Lake Michigan was collected in Niskin bottles from a depth of $2-4 \mathrm{~m}$ at a station approximately one mile west of Grand Haven, Michigan on 12 September 1981. The water samples were pooled and stored in a precleaned, acidwashed opaque carboy and held at $20.5^{\circ} \mathrm{C}$, which was the water temperature at collection, until the sample was returned to the laboratory that evening. The sample was stored in a growth chamber overnight at the collection temperature, then subsequently divided into eight $2-\mathrm{L}$ flasks. Nutrients and lead were then added according to the treatment schedule in Table 1. Samples were withdrawn for chemical analysis at $0,2,6$. and 48 hr with the time 0 samples withdrawn immediately after the addition of nutrients. Samples for electron microscopy were withdrawn at 2 and $48 \mathrm{hr}$.

The treatment flasks were placed on a rotary shaker table in a growth chamber set at $20.5^{\circ} \mathrm{C}, 14: 10$ day/night cycle, and a light intensity of $200 \mu \mathrm{ein} / \mathrm{m}^{-2} / \mathrm{sec}^{-1}$. Samples for chemical analyses were filtered through $25 \mathrm{~mm}$ HA Millipore filters which were previously soaked and rinsed several times with distilled deionized water. Filter blanks were analyzed to insure that no nutrients were added by the use of filters. Nutrient analyses were made on filtered samples with a Technicon AutoAnalyzer II equipped to measure five nutrients simultaneously - nitrate plus nitrite nitrogen, ammonia nitrogen, soluble reactive silica, chloride, and soluble reactive phosphorus. All methods of chemical analyses were those previously used by Schelske et al. $(1972$, 1976). With some modifications, these are the methods given by Davis and Simmons (1979) and Schelske et al. (1980).

Dissolved reactive silica was determined by the heteropoly blue method. In this method, silica is complexed with acidified molybdate to form a silicomolybdate complex which is reduced to an intense heteropoly blue. Oxalic acid was added prior to the reduction with ascorbic acid to destroy any phosphomolybdate. The color produced was measured at $630 \mathrm{~nm}$. Data are reported as $\mathrm{mg} \mathrm{SiO}_{2} / \mathrm{L}$.

Nitrate was reduced with copper-hydrazine solution to nitrite at $54^{\circ} \mathrm{C}$. The nitrite produced and the nitrite present in the sample were determined by a diazotization-coupling reaction using sulfanilamide and N-1-napthyl-ethylene diamine. The resulting red-violet color complex was measured at $520 \mathrm{~nm}$ (Kamphake et al. 1967) and reported as $\mu \mathrm{g} \mathrm{NO}_{3}-\mathrm{N} / \mathrm{L}$. Nitrite was not analyzed separately, because quantitatively insignificant values
Table 1. Treatments and levels of added nutrients and metal

\begin{tabular}{llc}
\hline Treatment & Addition & Designation \\
\hline None & None & $\mathrm{P}_{1}, \mathrm{Si}_{1}, \mathrm{~Pb}_{1}$ \\
$\mathrm{P}$ & $8 \mu \mathrm{g} \mathrm{P} / \mathrm{L}$ & $\mathrm{P}_{2}, \mathrm{Si}_{1}, \mathrm{~Pb}_{1}$ \\
$\mathrm{Si}$ & $1 \mathrm{mg} \mathrm{SiO} / \mathrm{L}$ & $\mathrm{P}_{1}, \mathrm{Si}_{2}, \mathrm{~Pb}_{1}$ \\
$\mathrm{~Pb}$ & $30 \mu \mathrm{g} \mathrm{Pb} / \mathrm{L}$ & $\mathrm{P}_{1}, \mathrm{Si}_{1}, \mathrm{~Pb}_{2}$ \\
$\mathrm{P}+\mathrm{Si}$ & $8 \mu \mathrm{g} \mathrm{P} / \mathrm{L}+1 \mathrm{mg} \mathrm{SiO} / \mathrm{L}$ & $\mathrm{P}_{2}, \mathrm{Si}_{2}, \mathrm{~Pb}_{1}$ \\
$\mathrm{P}+\mathrm{Si}+\mathrm{Pb}$ & $8 \mu \mathrm{g} \mathrm{P} / \mathrm{L}+1 \mathrm{mg} \mathrm{SiO} / \mathrm{L}$ & \\
& $+30 \mu \mathrm{Pb} / \mathrm{L}$ & $\mathrm{P}_{2}, \mathrm{Si}_{2}, \mathrm{~Pb}_{2}$ \\
$\mathrm{P}+\mathrm{Pb}$ & $8 \mu \mathrm{g} \mathrm{P} / \mathrm{L}+30 \mu \mathrm{gb} / \mathrm{L}$ & $\mathrm{P}_{2}, \mathrm{Si}_{1}, \mathrm{~Pb}_{2}$ \\
$\mathrm{~S}+\mathrm{Pb}$ & $1 \mathrm{mg} \mathrm{SiO} / \mathrm{L}+30 \mu \mathrm{g} \mathrm{Pb} / \mathrm{L}$ & $\mathrm{P}_{1}, \mathrm{Si}_{2}, \mathrm{~Pb}_{2}$ \\
\hline
\end{tabular}

a Treatments with a subscript of 1 designate ambient lake levels; subscripts of 2 designate nutrient or metal additions

would be expected in non-polluted oxygenated waters (Mortonson and Brooks 1980).

Ammonia and ammonium ions were measured by conversion of ammonium ions to ammonia in a basic medium. Ammonia reacts with hypochlorite and phenol to produce an indolphenol blue color which was measured at $630 \mathrm{~nm}$. The reaction was catalyzed by nitro-prusside, and EDTA was added to prevent precipitation of alkali earth metals.

Soluble reactive phosphorus was measured by formation of antimony-phosphomolybdate complex in acid medium which was reduced by ascorbic acid and measured at $880 \mathrm{~nm}$. Data are reported as $\mu \mathrm{g} \mathrm{P} / \mathrm{L}$.

Chloride was determined from its reaction with mercuric thiocyanate that forms ionized but soluble mercuric chloride. The released thiocyanate in the presence of a ferric ion reacts to form a red thiocyanate complex. The resulting color was measured at $480 \mathrm{~nm}$. Data are reported as $\mathrm{mg} \mathrm{Cl} / \mathrm{L}$.

For electron microscopy, paraformaldehyde, glutaraldehyde, and sodium cacodylate were added to the samples containing lake water and the phytoplankton assemblage to give a solution with final concentrations of $1 \%$ paraformaldehyde, $1 \%$ glutaraldehyde, $0.05 \mathrm{M}$ sodium cacodylate, with a $\mathrm{pH}$ of 7.2 and an osmolality of 515 milliosmoles (Lazinsky and Sicko-Goad 1979). Samples were post-fixed in $1 \%$ osmium tetroxide in cacodylate buffer for $1 \mathrm{hr}$ at $4^{\circ} \mathrm{C}$. The fixed cells were dehydrated in a graded ethanol and propylene oxide series during a time period of approximately $1.5 \mathrm{hr}$ and embedded in Epon (Luft 1961).

Thin sections were cut with a diamond knife, collected on formvar coated 200 mesh copper grids and stained with aqueous uranyl acetate (Watson 1958), Sections were examined at a standard magnification of $39,600 \times$ in a JEOL JEM $100 \mathrm{~B}$ electron microscope operating at $80 \mathrm{kV}$. Microscope magnification calibrations were made by use of a grating replica to determine the stability of the standard magnification. Variation was between 1 and $2 \%$. Samples were photographed for morphometric and ultrastructural studies as previously described (Sicko-Goad et al. 1977; Sicko-Goad 1982).

The water samples were examined for species composition and abundance. Three blue-greens (Anacystis incerta, Gomphosphaeria lacustris, Anacystis thermalis) and two diatoms (Stephanodiscus tenuis and Cyclotella sp.) were relatively abundant in the assemblage and easily identifiable. However, the blue-green populations were somewhat abnormal in morphology, probably because the populations were waning in the lake. Consequently, the most abundant diatom, Cyclotella sp. (Cyclotella aff. commensis) was selected for extensive morphological studies. 


\section{Statistical Methodology}

The experiment was designed as a completely crossed factorial enrichment, consisting of 2 levels each of phosphorus, silica and lead sampled at 2 different time points (Table 1). For each, Level 1 was the ambient lake concentration and Level 2 was a Time 0 spike.

Thirty micrographs of randomly-selected sections from thirty different cells were examined for each treatment. Estimates of relative volume fractions $\left(V_{v}\right)$ of cellular components and of numbers per unit volume $\left(\mathrm{N}_{\mathrm{v}}\right)$ of mitochondria were determined. using morphometric methods based on grid point-counting (Sicko-Goad et al. 1977; Sicko-Goad 1982).

Derivations of some of the common morphometric relationships assume a constant test area or constant length linear probe across all samples (e.g. the derivations of $V_{v}=A_{A}$ and $A_{A}=L_{L}$ in DeHoff and Rhines (1968) and Underwood (1970), among others). However, for single-celled organisms such as Crclotella, cell cross-sectional ared (and therefore the test area, length, or point count) generally varies substantially from micrograph to micrograph, depending on where and at what angle the sampling plane intersects the cell.

Two different formulations of the Delesse principle are:

$$
\frac{V_{C}}{V_{T}}=E\left(\frac{A_{C}}{A_{T}}\right)
$$

which is estimated by:

$$
\frac{V_{C}}{V_{T}}-\left(\overline{\frac{A_{C}}{A_{T}}}\right)
$$

and

$$
\frac{V_{C}}{V_{T}}=\frac{E\left(A_{C}\right)}{E\left(A_{T}\right)}
$$

which is estimated by

$$
\frac{V_{C}}{V_{T}}-\frac{\bar{A}_{C}}{\bar{A}_{T}}
$$

Formulation (2) is equivalent to computing a weighted average of the $\left(A_{C} / A_{T}\right)_{i}$ ratios, with weights $\left[W_{i}=\left(A_{T}\right)_{i} / \Sigma\left(A_{T}\right)_{i}\right]$ based on the fraction of total points each cell cross-section contains; this formulation is also equivalent to making morphometric measurements on a single tissue montage composed of all the cell crosssections. Formulation (1) is based on the assumption of equal sampling areas; formulation (2) has more general applicability. The two formulations reduce to the same quantity only if the assumption of equal sampling areas is valid.

Formulation (2) has the limitation that it does not permit the calculation of a variance estimate. Lorenz (1977) in morphometric studies of the single-celled organism Chlorella, describes the "Grouping Method" for calculating variance estimates, in which subgroup means are calculated using formulation (2) and a grand mean is calculated from the subgroup means using formulation (1). In the case of Chlorella, a subgroup size $\mathrm{n}=12$ yields a grand mean with a negligibly small bias (Lorenz 1977).

The "Grouping Method" (with number of subgroups $=3$ and subgroup size $=10$ ) is used in this paper to generate replicates for use in the statistical analyses. Grouping produces subgroup montages which all have approximately the same sampling area; therefore the assumption of equal sampling areas is approximately met when formulation (1) is applied to the subgroup means. It should be noted that statistical analyses such as ANOVA perform a mean calculation as in formulation (1).

A four-way completely-crossed ANOVA $(2 \mathrm{Si} \times 2 \mathrm{P} \times 2 \mathrm{~T} \times$ $2 \mathrm{~Pb}$ ) was used to analyze the short-term cellular responses to spikes of nutrients and $\mathrm{Pb}$. The cellular components determined to be of a priori interest were chloroplast $\mathrm{V}_{\mathrm{v}}$. mitochondria $\mathrm{V}_{\mathrm{v}}$, mitochondria $N_{v}$, storage $V_{v}$, nuclear $V_{v}$, vacuole $V_{v}$, and autophagic vacuole $V_{v}$; other components were analyzed to check for unpredicted effects. Treatments were judged to be significantly different at $P<.05$. Paraliel univariate ANOVAs performed on data derived from the same micrographs introduce a problem with controlling $\alpha$; therefore, actual $P$ values may be somewhat higher than those caiculated in the analysis.

Since the cell and not the flask is the unit of experimental interest, replicate cells rather than replicate flasks were used to estimate the mean square error term in the ANOVA. Variability in cellular composition between flasks is in general small compared to the random variability observed among cels within flasks, due to such factors as the sampling of cells from all stages of the growth cycle and the measuring of cellular components that are in general not randomly distributed throughout the cell. However. the fraction of the total variance accounted for by random variability between replicate flasks cannot be estimated and remains unseparated from the variability contributed by nutrient and $\mathrm{Pb}$ enrichments.

Statistical analyses were performed with the assistance of the MIDAS and BMDP statistical packages available through the computing facilities at the University of Michigan.

\section{Results}

Micrographs of both untreated and treated cells (Figures $1-4$ ) reveal that although individual cells may be found that exhibit some of the quantitative features listed below, there is no gross, readily discernible difference between treatments at such low metal levels. For example, autophagic vacuoles (AV) may be found in short-term incubations ( $2 \mathrm{hr}$ ) with no metal or nutrient additions (Figure 1) as well as in the treated samples (Figures $2-3$ ). Similarly, storage products (S) are found in all treatments (Figures 2-4). The absence of gross ultrastructural differences by visual observation alone is quite striking.

\section{General Descriptive Measures}

The quantitative results presented in this study describe both physical and physiological compartments of the cell. For the morphological results that follow, measurements are made as relative volumes $\left(V_{v}\right)$ which are the percentage of the cell volume occupied by a particular organelle or inclusion. Number per volume $\left(\mathrm{N}_{\mathrm{v}}\right)$ refers to the numbers of organelles found per $\mu \mathrm{m}^{3}$ cell. 

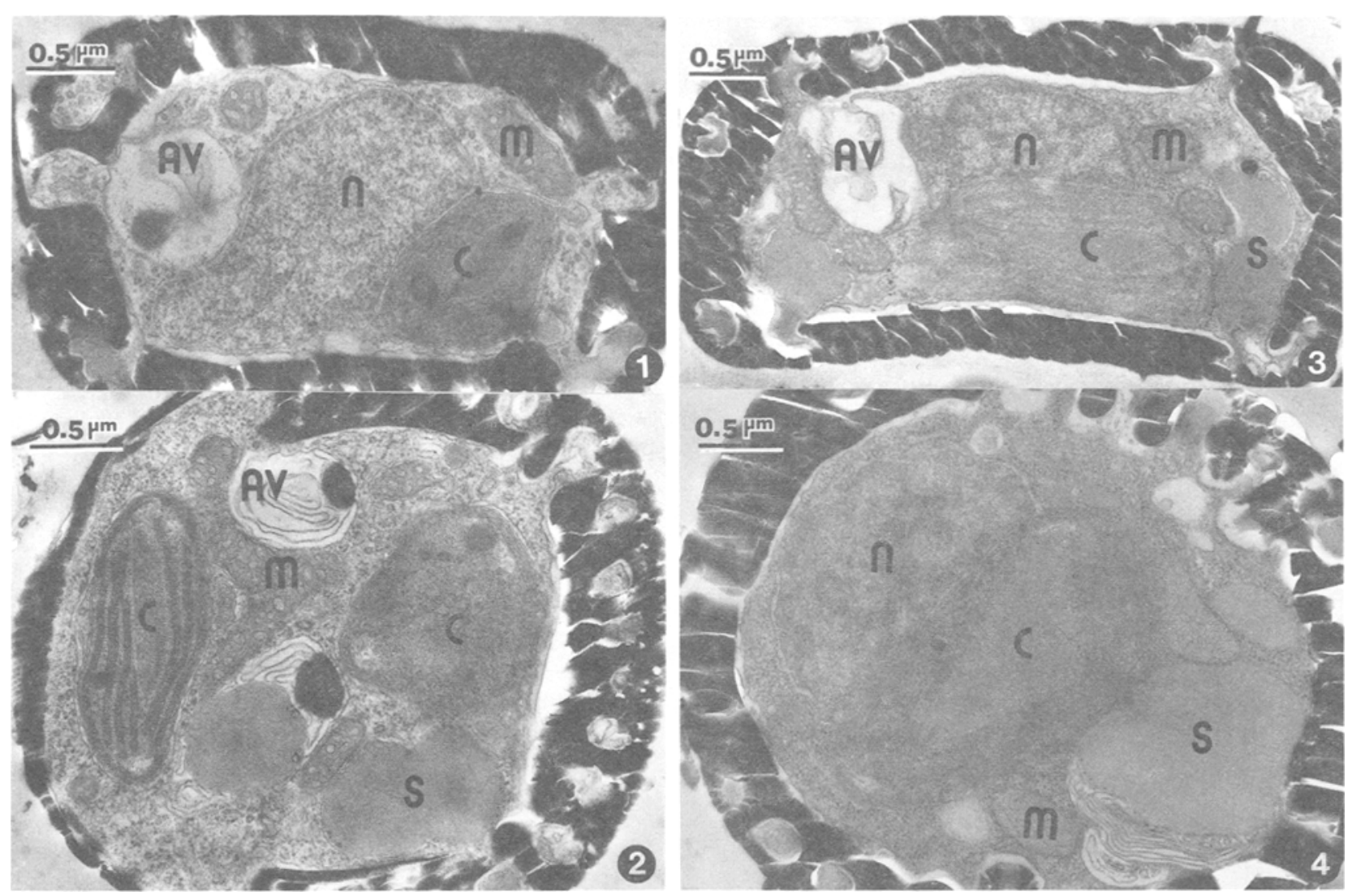

Figs. 1-4. Cyclotella sp. Autophagic vacuole (AV), chloroplast (C), mitochondria (M). nucleus (N). storage (S) 1 . Cell after 2 hr with no treatment 2. Cell treated with silica and lead for $2 \mathrm{hr}$ 3. Two hr sample of cell treated with additions of phosphate, silica, and lead 4. Cell after $48 \mathrm{hr}$ treatment with phosphate, silica, and lead additions

\section{Nutrients}

Water chemistry data are presented in Table 2. The ambient levels of $\mathrm{PO}_{4}$ and $\mathrm{SiO}_{2}$ were $0.4 \mu \mathrm{g} / \mathrm{L}$ and $0.4 \mathrm{mg} / \mathrm{L}$ respectively. With spikes of either lead or silica, the phosphate decreases to levels of less than $0.2 \mu \mathrm{g} / \mathrm{L}$ within $2 \mathrm{hr}$ while silica levels remain constant. In treatments where phosphate is added as a spike, the amount of available phosphorus is approximately $2 \mu \mathrm{g} / \mathrm{L}$ after six hr of incubation. The levels of chloride, silica, and nitrate are rather consistent across time and treatment showing little measurable change during the $6 \mathrm{hr}$ sampling interval. Since $\mathrm{PO}_{4}$ and $\mathrm{SiO}_{2}$ were essentially depleted at $6 \mathrm{hr}$, the $48 \mathrm{hr}$ samples were not analyzed. Nutrient levels in the combination treatments were not significantly different.

\section{Cell Morphology}

The results of the morphometric study are presented in Tables 3 and 4 . The data are divided into the two sampling periods of 2 and $48 \mathrm{hr}$ for ease of comparison. Although $\mathrm{PO}_{4}$ and $\mathrm{SiO}_{2}$ were essentially depleted at $6 \mathrm{hr}$, the $48 \mathrm{hr}$ microscopy samples were analyzed to determine the long-term effects on Cyclotella in the assemblage. Incubations longer than $48 \mathrm{hr}$ may result in significant changes in species composition due to competition and other natural selection processes. The treatment codes are listed in the Figure legends. However, all subscripts labelled 1 are ambient lake levels whereas all subscripts labelled 2 are metal or nutrient addition treatments. The data are discussed under the following categories:

Chloroplast: There was a statistically significant ( $\mathrm{P}$ $<.01$ ) reduction in chloroplast relative volume from time 1 to time 2, or within a $48 \mathrm{hr}$ period. In all cases, the larger decrease in chloroplast volume fraction occurred at the ambient (lake) $P$ level rather than in the spiked $\mathrm{P}$ treatment, suggesting that the long-term (after $48 \mathrm{hr}$ ) decrease in chloroplast volume fraction may be due at least partially 
Table 2. Chemistry data for Lake Michigan experiment. September 1981

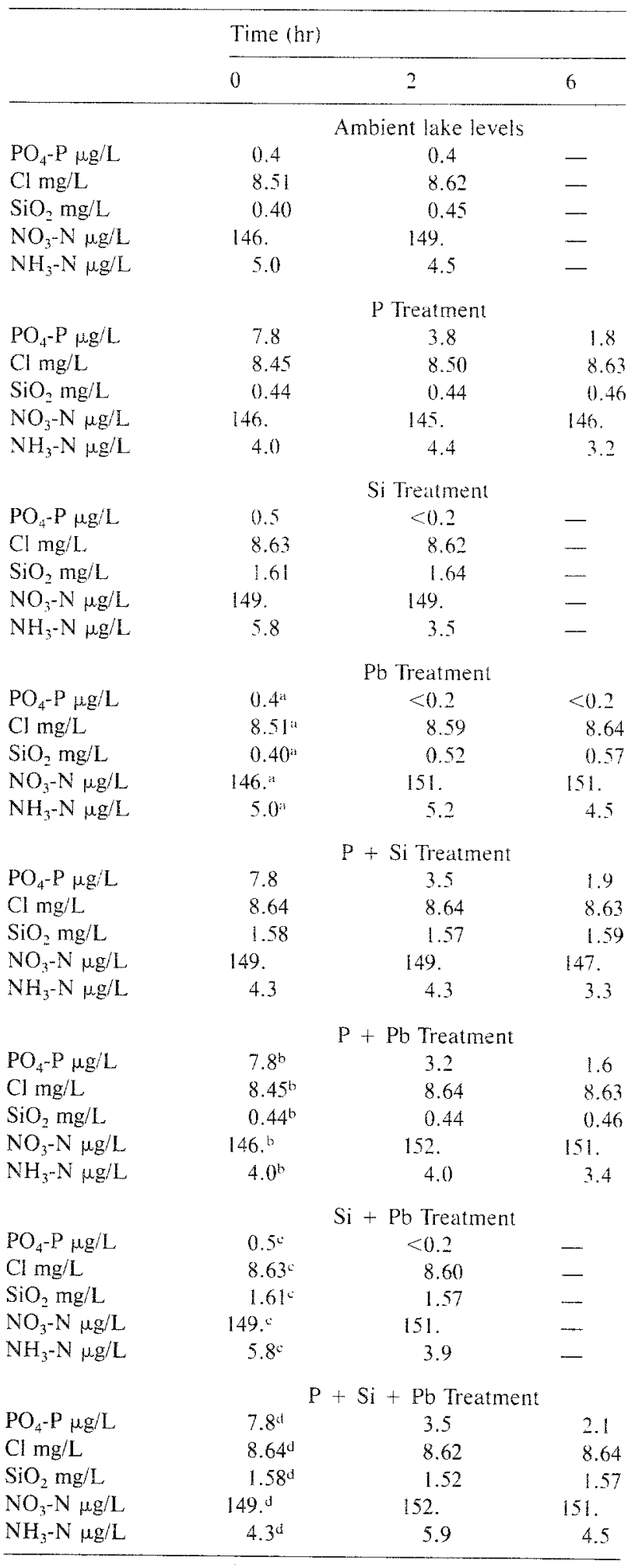

a Values are time 0 no treatment samples

b Values are time $0 \mathrm{P}$ treatment

cValues are time $0 \mathrm{Si}$ treatment

${ }^{d}$ Values are time $0 \mathrm{P}+\mathrm{Si}$ treatment to the effects of phosphate limitation. Cells with the largest chloroplast volume fractions generally occurred in $P_{2} T_{2}$ samples. Cells exposed to spikes of phosphorus showed a consistent short-term (within $2 \mathrm{hr}$ ) decrease in chloroplast percent. There was a substantial decrease in chloroplast percent with the addition of lead alone. Adding $\mathrm{P}$ and/or $\mathrm{SiO}_{2}$ with lead seemed to minimize this chloroplast reduction.

Mitochondria: The ANOVA results demonstrate that there is a significant $(\mathrm{P}<.05)$ silica-phosphorus interaction in mitochondrial relative volume. At ambient silica levels $\left(\mathrm{Si}_{1}\right)$, there was a small fraction with added $P$; in treatments with silica spikes $\left(\mathrm{Si}_{2}\right)$, mitochondrial fraction generally decreased with added P. However, the major change in mitochondrial volume fraction occurred in treatments $\mathrm{Si}_{2} \mathrm{P}_{1}$, where a large long-term tafter $48 \mathrm{hr}$ ) increase in mitochondrial volume fraction was observed following exposure to elevated silica level.

The ANOVA results demonstrated a significant $(\mathrm{P}<.001)$ phosphorus-time interaction for numbers of mitochondria per volume. Cells exposed to phosphorus spikes $\left(\mathrm{P}_{2}\right)$ showed a small short-term (within $2 \mathrm{hr}$ ) increase in mitochondrial $\mathrm{N}_{\mathrm{v}}: \mathrm{N}_{\mathrm{v}}$ then remained constant for the remainder of the experiment. Cells grown in ambient phosphorus concentrations $\left(\mathrm{P}_{1}\right)$ showed a long-term (after $48 \mathrm{hr}$ ) increase in mitochondrial $N_{v}$. The addition of lead or silica seems to have little systematic effect on mitochondrial numbers.

Storage Products: There was a significant increase in storage products in the cell with both time ( $P<$ $.0001)$ and lead $(P<.05)$. A greater increase in storage was observed across time with added $P$, although this trend is not statistically significant. The greatest observed percentage of storage products was found at $\mathrm{P}_{2} \mathrm{~Pb}_{2} \mathrm{~T}_{2}$.

Nucleus: There was a statistically significant $(\mathrm{P}<$ $.05)$ increase in nuclear relative volume with added phosphorus. However, cell volume was also greater at ambient phosphorus levels, indicating that phosphorus may stimulate cell division and explain the apparent increase in nuclear $V_{v}$.

Vacuole: There were statistically significant interactions of phosphorus-time $(\mathrm{P}<.001)$ and silica-lead $(\mathrm{P}<.05)$ on vacuole relative volume. Cells exposed to phosphorus spikes $\left(\mathrm{P}_{2}\right)$ showed a large shortterm (within $2 \mathrm{hr}$ ) increase in vacuole volume fraction. Within $48 \mathrm{hr}$ the vacuole fraction decreased to values close to those found at $2 \mathrm{hr}$ with no added $\mathrm{P}$. 
Table 3. Morphometric results of 2-hr experimental treatments. Numbers reported are relative volumes $(\% /$ ) or numbers per volume $\left(\mathrm{N}_{v}\right)$. Treatment codes are listed below. Numbers in parentheses are standard errors

\begin{tabular}{|c|c|c|c|c|c|c|c|c|}
\hline & $\mathrm{P}_{1} \mathrm{Si}_{1} \mathrm{~Pb}_{1}$ & $\mathrm{P}_{1} \mathrm{Si}_{1} \mathrm{~Pb}_{2}$ & $\mathrm{P}_{1} \mathrm{Si}_{2} \mathrm{~Pb}_{1}$ & $\mathrm{P}_{1} \mathrm{Si}_{2} \mathrm{~Pb}_{2}$ & $\mathrm{P}_{2} \mathrm{Si}_{1} \mathrm{~Pb}_{1}$ & $\mathrm{P}_{2} \mathrm{Si}_{1} \mathrm{~Pb}_{2}$ & $\mathrm{P}_{2} \mathrm{Si}_{2} \mathrm{~Pb}_{1}$ & $\mathrm{P}_{2} \mathrm{Si}_{2} \mathrm{~Pb}_{2}$ \\
\hline Chloroplast $\%$ & $\begin{array}{l}12.62 \\
(1.64)\end{array}$ & $\begin{array}{l}10.79 \\
(1.19)\end{array}$ & $\begin{array}{l}12.69 \\
(1.25)\end{array}$ & $\begin{array}{l}12.19 \\
(1.11)\end{array}$ & $\begin{array}{l}11.39 \\
(1.37)\end{array}$ & $\begin{array}{l}11.67 \\
(1.23)\end{array}$ & $\begin{array}{l}10.61 \\
(1.29)\end{array}$ & $\begin{array}{l}11.08 \\
(1.46)\end{array}$ \\
\hline Mitochondria $\%$ & $\begin{array}{c}4.18 \\
(0.50)\end{array}$ & $\begin{array}{c}4.96 \\
(0.62)\end{array}$ & $\begin{array}{c}3.80 \\
(0.38)\end{array}$ & $\begin{array}{c}5.25 \\
(0.54)\end{array}$ & $\begin{array}{c}5.05 \\
(0.45)\end{array}$ & $\begin{array}{c}5.61 \\
(0.43)\end{array}$ & $\begin{array}{c}4.46 \\
(0.47)\end{array}$ & $\begin{array}{c}4.61 \\
(0.40)\end{array}$ \\
\hline Mitochondria $\mathrm{N}_{v}$ & $\begin{array}{c}0.41 \\
(0.05)\end{array}$ & $\begin{array}{c}0.41 \\
(0.11)\end{array}$ & $\begin{array}{c}0.31 \\
(0.04)\end{array}$ & $\begin{array}{c}0.41 \\
(0.05)\end{array}$ & $\begin{array}{c}0.47 \\
(0.04)\end{array}$ & $\begin{array}{c}0.47 \\
(0.04)\end{array}$ & $\begin{array}{c}0.58 \\
(0.07)\end{array}$ & $\begin{array}{c}0.42 \\
(0.06)\end{array}$ \\
\hline Storage $\%$ & $\begin{array}{c}1.48 \\
(0.41)\end{array}$ & $\begin{array}{c}2.68 \\
(0.41)\end{array}$ & $\begin{array}{c}2.32 \\
(0.55)\end{array}$ & $\begin{array}{c}2.39 \\
(0.50)\end{array}$ & $\begin{array}{c}0.99 \\
(0.39)\end{array}$ & $\begin{array}{c}2.07 \\
(0.53)\end{array}$ & $\begin{array}{c}1.71 \\
(0.44)\end{array}$ & $\begin{array}{c}1.65 \\
(0.31)\end{array}$ \\
\hline Nucleus $\%$ & $\begin{array}{c}9.17 \\
(1.39)\end{array}$ & $\begin{array}{c}6.86 \\
(1.18)\end{array}$ & $\begin{array}{c}9.48 \\
(1.32)\end{array}$ & $\begin{array}{c}7.32 \\
(1.28)\end{array}$ & $\begin{array}{c}9.83 \\
(1.33)\end{array}$ & $\begin{array}{l}10.77 \\
(1.19)\end{array}$ & $\begin{array}{c}9.35 \\
(1.30)\end{array}$ & $\begin{array}{c}9.02 \\
(1.30)\end{array}$ \\
\hline Other \% & $\begin{array}{l}20.18 \\
(1.27)\end{array}$ & $\begin{array}{l}20.67 \\
(0.94)\end{array}$ & $\begin{array}{l}21.63 \\
(1.30)\end{array}$ & $\begin{array}{l}21.15 \\
(0.84)\end{array}$ & $\begin{array}{l}21.57 \\
(0.87)\end{array}$ & $\begin{array}{l}19.05 \\
(1.23)\end{array}$ & $\begin{array}{l}20.88 \\
(1.25)\end{array}$ & $\begin{array}{l}20.42 \\
(1.26)\end{array}$ \\
\hline Vacuole $\%$ & $\begin{array}{c}5.04 \\
(0.43)\end{array}$ & $\begin{array}{c}5.29 \\
(0.38)\end{array}$ & $\begin{array}{c}5.89 \\
(0.68)\end{array}$ & $\begin{array}{c}4.33 \\
(0.42)\end{array}$ & $\begin{array}{c}6.74 \\
(0.78)\end{array}$ & $\begin{array}{c}6.94 \\
(1.09)\end{array}$ & $\begin{array}{c}6.77 \\
(0.71)\end{array}$ & $\begin{array}{c}5.52 \\
(0.53)\end{array}$ \\
\hline Frustule $\%$ & $\begin{array}{l}39.90 \\
(1.31)\end{array}$ & $\begin{array}{l}42.41 \\
(0.96)\end{array}$ & $\begin{array}{l}40.00 \\
(1.50)\end{array}$ & $\begin{array}{l}39.16 \\
(1.16)\end{array}$ & $\begin{array}{l}40.23 \\
(1.31)\end{array}$ & $\begin{array}{l}38.14 \\
(1.02)\end{array}$ & $\begin{array}{l}40.32 \\
(1.59)\end{array}$ & $\begin{array}{l}41.46 \\
(1.48)\end{array}$ \\
\hline Autophagic vacuole $\%$ & $\begin{array}{c}7.39 \\
(0.90)\end{array}$ & $\begin{array}{c}6.17 \\
(0.91)\end{array}$ & $\begin{array}{c}4.05 \\
(0.75)\end{array}$ & $\begin{array}{c}8.05 \\
(0.92)\end{array}$ & $\begin{array}{c}4.00 \\
(0.82)\end{array}$ & $\begin{array}{c}5.64 \\
(0.83)\end{array}$ & $\begin{array}{c}5.81 \\
(1.03)\end{array}$ & $\begin{array}{c}6.18 \\
(1.04)\end{array}$ \\
\hline Polyphosphate \% & $\begin{array}{c}0.05 \\
(0.03)\end{array}$ & $\begin{array}{c}0.16 \\
(0.08)\end{array}$ & $\begin{array}{c}0.15 \\
(0.07)\end{array}$ & $\begin{array}{c}0.15 \\
(0.07)\end{array}$ & $\begin{array}{c}0.19 \\
(0.07)\end{array}$ & $\begin{array}{c}0.12 \\
(0.08)\end{array}$ & $\begin{array}{c}0.09 \\
(0.05)\end{array}$ & $\begin{array}{c}0.07 \\
(0.07)\end{array}$ \\
\hline
\end{tabular}

$\mathrm{P}_{1}=$ ambient (lake level) $\mathrm{P}, \mathrm{Si}_{1}=$ ambient silica, $\mathrm{Pb}_{1}=$ ambient lead. $\mathrm{P}_{2}=8 \mu \mathrm{g} \mathrm{P} / \mathrm{L}$ added. $\mathrm{Si}_{2}=1 \mathrm{mg} \mathrm{SiO} \mathrm{O}_{2}$ added, $\mathrm{Pb}=30 \mu \mathrm{gb}$ added

At ambient phosphorus levels $\left(\mathrm{P}_{1}\right)$, vacuole relative volume increased with time. This implies that adding phosphorus temporarily increases vacuole $\mathrm{V}_{\mathrm{v}}$. It also implies that phosphorus depletion increases vacuole relative volume.

At ambient silica levels there was little change in vacuole $V_{v}$ with added lead. In the spiked silica treatments, there was a decrease in vacuole relative volume with added lead. The lowest vacuole $V_{v}$ values were found for each phosphorus-time group in treatments with added silica and lead. The highest vacuole $V_{v}$ 's were found in treatments with added silica but no lead.

Autophagic Vacuole $(A V)$ : There was a variety of significant treatment interactions for $\mathrm{AV}$ relative volume: $\mathrm{SP}(\mathrm{P}<.01)$ and $\mathrm{LT}(\mathrm{P}<.0001)$ two-way interactions, and SLP $(\mathrm{P}<.001)$ and SLT $(\mathrm{P}<.05)$ three-way interactions. At ambient lead levels, AV relative volume increased with time. Cells exposed to spikes of lead showed decreases in AV fraction with time; the largest decreases in AV fraction with time were observed in cells exposed to spikes of both lead and silica.

At ambient silica and lead levels, AV relative volumes decreased with added P. Cells exposed to spikes of silica showed increases in AV fraction with added P. Cells exposed to spikes of both silica and lead showed varying responses depending upon the time the cells were sampled.

The following summarizes the ANOVA factors and the significant $(\mathrm{P}<.05)$ effects on cellular components:

Time: There was a significant decrease in chloroplast volume from 2 to $48 \mathrm{hr}$. There was also a significant increase in storage from 2 to $48 \mathrm{hr}$.

Lead: There was a small but significant increase in storage products with added lead.

Phosphorus: There was a significant increase in nuclear relative volume with added phosphorus.

Silica-Phosphorus Interaction: Mitochondrial relative volume showed little change from 2 to $48 \mathrm{hr}$ at ambient $\mathrm{P}$ and silica levels. Cells exposed to ambient $P$ conditions but with added silica showed an increase in mitochondrial $\mathrm{N}_{\mathrm{v}}$.

Phosphorus-Time Interaction: Cells exposed to ambient $\mathrm{P}$ levels showed a large increase in mito- 
Table 4. Morphometric results of 48-hr experimental treatments. Numbers reported are relative volumes (\%) or numbers per volume $\left(\mathrm{N}_{\mathrm{v}}\right)$. Treatment codes are listed below. Numbers in parentheses are standard errors

\begin{tabular}{|c|c|c|c|c|c|c|c|c|}
\hline & $P_{1} \mathrm{Si}_{1} \mathrm{~Pb}_{1}$ & $\mathrm{P}_{1} \mathrm{Si}_{1} \mathrm{~Pb}_{2}$ & $\mathrm{P}_{1} \mathrm{Si}_{2} \mathrm{~Pb}_{1}$ & $\mathrm{P}_{1} \mathrm{Si}_{2} \mathrm{~Pb}_{2}$ & $\mathrm{P}_{2} \mathrm{Si}_{1} \mathrm{~Pb}_{1}$ & $\mathrm{P}_{2} \mathrm{Si}_{1} \mathrm{~Pb}_{2}$ & $\mathrm{P}_{2} \mathrm{Si}_{2} \mathrm{~Pb}_{1}$ & $\mathrm{P}_{2} \mathrm{Si}_{2} \mathrm{~Pb}_{2}$ \\
\hline Chloroplast $\%$ & $\begin{array}{l}10.78 \\
(1.16)\end{array}$ & $\begin{array}{c}8.55 \\
(1.25)\end{array}$ & $\begin{array}{c}9.23 \\
(1.28)\end{array}$ & $\begin{array}{l}10.96 \\
(1.16)\end{array}$ & $\begin{array}{l}10.07 \\
(1.03)\end{array}$ & $\begin{array}{l}10.19 \\
(1.11)\end{array}$ & $\begin{array}{c}7.76 \\
(0.83)\end{array}$ & $\begin{array}{l}10.64 \\
(1.15)\end{array}$ \\
\hline Mitochondria $\%$ & $\begin{array}{c}4.34 \\
(0.31)\end{array}$ & $\begin{array}{c}5.22 \\
(0.36)\end{array}$ & $\begin{array}{c}6.07 \\
(0.49)\end{array}$ & $\begin{array}{c}6.27 \\
(0.63)\end{array}$ & $\begin{array}{c}5.43 \\
(0.59)\end{array}$ & $\begin{array}{c}5.45 \\
(0.53)\end{array}$ & $\begin{array}{c}4.61 \\
(0.38)\end{array}$ & $\begin{array}{c}4.84 \\
(0.45)\end{array}$ \\
\hline Mitochondria $\mathrm{N}_{\mathrm{v}}$ & $\begin{array}{c}0.64 \\
(0.07)\end{array}$ & $\begin{array}{c}0.64 \\
(0.08)\end{array}$ & $\begin{array}{c}0.61 \\
(0.07)\end{array}$ & $\begin{array}{c}0.57 \\
(0.05)\end{array}$ & $\begin{array}{c}0.46 \\
(0.06)\end{array}$ & $\begin{array}{c}0.51 \\
(0.05)\end{array}$ & $\begin{array}{c}0.52 \\
(0.06)\end{array}$ & $\begin{array}{c}0.47 \\
(0.05)\end{array}$ \\
\hline Storage $\%$ & $\begin{array}{c}5.49 \\
(0.82)\end{array}$ & $\begin{array}{c}6.12 \\
(1.04)\end{array}$ & $\begin{array}{c}4.17 \\
(0.61)\end{array}$ & $\begin{array}{c}5.65 \\
(1.06)\end{array}$ & $\begin{array}{c}6.20 \\
(0.96)\end{array}$ & $\begin{array}{c}6.59 \\
(1.03)\end{array}$ & $\begin{array}{c}4.01 \\
(0.85)\end{array}$ & $\begin{array}{c}7.61 \\
(1.16)\end{array}$ \\
\hline Nucleus $\%$ & $\begin{array}{c}6.59 \\
(1.09)\end{array}$ & $\begin{array}{c}7.91 \\
(1.28)\end{array}$ & $\begin{array}{c}7.76 \\
(1.33)\end{array}$ & $\begin{array}{c}7.91 \\
(1.20)\end{array}$ & $\begin{array}{c}8.47 \\
(1.48)\end{array}$ & $\begin{array}{l}10.29 \\
(1.36)\end{array}$ & $\begin{array}{c}9.60 \\
(1.21)\end{array}$ & $\begin{array}{c}8.61 \\
(1.19)\end{array}$ \\
\hline Other $\%$ & $\begin{array}{l}19.19 \\
(0.97)\end{array}$ & $\begin{array}{l}19.35 \\
(1.27)\end{array}$ & $\begin{array}{l}19.60 \\
(0.87)\end{array}$ & $\begin{array}{l}20.02 \\
(0.90)\end{array}$ & $\begin{array}{c}20.52 \\
(1.11)\end{array}$ & $\begin{array}{l}19.15 \\
(1.30)\end{array}$ & $\begin{array}{l}19.76 \\
(1.11)\end{array}$ & $\begin{array}{c}21.34 \\
(0.84)\end{array}$ \\
\hline Vacuole $\%$ & $\begin{array}{c}6.19 \\
(0.60)\end{array}$ & $\begin{array}{c}7.40 \\
(0.94)\end{array}$ & $\begin{array}{c}7.73 \\
(0.80)\end{array}$ & $\begin{array}{c}6.08 \\
(0.54)\end{array}$ & $\begin{array}{c}5.10 \\
(0.63)\end{array}$ & $\begin{array}{c}4.88 \\
(0.46)\end{array}$ & $\begin{array}{c}5.55 \\
(0.78)\end{array}$ & $\begin{array}{c}4.22 \\
(0.41)\end{array}$ \\
\hline Frustule \% & $\begin{array}{l}38.55 \\
(1.60)\end{array}$ & $\begin{array}{l}40.36 \\
(1.02)\end{array}$ & $\begin{array}{l}40.18 \\
(1.37)\end{array}$ & $\begin{array}{l}40.10 \\
(1.07)\end{array}$ & $\begin{array}{l}38.90 \\
(1.32)\end{array}$ & $\begin{array}{l}38.41 \\
(1.82)\end{array}$ & $\begin{array}{l}40.44 \\
(1.32)\end{array}$ & $\begin{array}{l}39.14 \\
(1.47)\end{array}$ \\
\hline Autophagic vacuole $\%$ & $\begin{array}{c}8.60 \\
(1.01)\end{array}$ & $\begin{array}{c}4.69 \\
(0.74)\end{array}$ & $\begin{array}{c}5.15 \\
(0.66)\end{array}$ & $\begin{array}{l}2.79 \\
(0.62)\end{array}$ & $\begin{array}{c}5.31 \\
(0.69)\end{array}$ & $\begin{array}{c}4.94 \\
(0.79)\end{array}$ & $\begin{array}{c}8.16 \\
(1.13)\end{array}$ & $\begin{array}{c}3.46 \\
(0.49)\end{array}$ \\
\hline Polyphosphate \% & $\begin{array}{c}0.28 \\
(0.14)\end{array}$ & $\begin{array}{c}0.41 \\
(0.22)\end{array}$ & $\begin{array}{c}0.10 \\
(0.08)\end{array}$ & $\begin{array}{c}0.22 \\
(0.11)\end{array}$ & $\begin{array}{l}0.00 \\
-\end{array}$ & $\begin{array}{c}0.10 \\
(0.06)\end{array}$ & $\begin{array}{c}0.12 \\
(0.08)\end{array}$ & $\begin{array}{c}0.13 \\
(0.08)\end{array}$ \\
\hline
\end{tabular}

$\mathrm{P}_{1}=$ ambient (lake level) $\mathrm{P}, \mathrm{Si}_{1}=$ ambient silica, $\mathrm{Pb}_{1}=$ ambient lead, $\mathrm{P}_{2}=8 \mu \mathrm{g} \mathrm{P} / \mathrm{L}$ added, $\mathrm{Si}_{2}=1 \mathrm{mg} \mathrm{SiO}$ added, $\mathrm{Pb}=30 \mu \mathrm{Pb}$ added

chondrial $\mathrm{N}_{\mathrm{v}}$ from 2 to $48 \mathrm{hr}$; very little change in mitochondrial $N_{v}$ across time was observed in $P_{2}$ treatments.

Vacuole relative volume also increased from 2 to $48 \mathrm{hr}$ under ambient $\mathrm{P}$ conditions. A decrease in vacuole relative volume across time was observed in $\mathrm{P}_{2}$ treatments.

Silica-Lead Interaction: There was little change in vacuole relative volume with added lead at ambient silica levels. However, there was a significant decrease in the vacuole fraction with added lead in the presence of added silica.

Silica-lead-time silica-lead-phosphorus interactions result in changes in the autophagic vacuole category.

\section{Discussion}

Previous reports have demonstrated that metals may be found as deposits in certain organelles (Silverberg 1976; Stuve and Galle 1970; Fujita et al. 1977; Daniel and Chamberlain 1981; Skaar et al. 1973; Choie and Richter 1972; Moore and Goyer 1974; Jensen et al. 1982; Baxter and Jensen 1980a, 1980b; Rachlin et al. 1984), or they may exert cytological effects without forming distinct deposits (Sicko-Goad and Stoermer 1979; Sicko-Goad 1982; Smith 1983; Canterford 1980; Saboski 1977; Rachlin et al. 1982, 1984, 1985). Many of the cytological changes that accompany heavy metal exposure are the result of damage to or alterations in membrane structure, producing swollen organelles or other osmotic disruptions (Sicko-Goad 1982; Smith 1983).

Some of the cytological modifications that have been reported to occur as a result of heavy metal exposure also occurred in Cyclotella, but it is apparent that the effects in some cases were mediated by the addition of low levels of nutrients. For example, chloroplast relative volume decreased both at 2 and $48 \mathrm{hr}$ in the presence of lead at ambient phosphorus levels. However, this reduction trend by lead was reversed with the addition of phosphorus. An example of a consistent trend in our data set is the increase in storage product volume with lead exposure across all treatment regimes.

The task of determining either synergistic or antagonistic interactions between toxicants and algae in their native environment is difficult, as is evidenced by our data. Environmental factors, such as chelation and binding, $\mathrm{pH}$, ionic interactions and 
temperature, which may be instrumental in altering the availability of free metal ions to cells, may also affect the physiological status of the cell, making data interpretation difficult, if not impossible, when changing more than one experimental variable.

Although data interpretation is more difficult in factorial design experiments, they do approximate the natural environment more closely where a variety of parameters may be changing simultaneously. Arguments similar to those developed by Thomas et al. (1980a) and Hollibaugh et al. (1980) also hold for studying the effect of nutrient conditioning on metal toxicity. The most obvious argument for conducting factorial design experiments is the fact that discharges of industrial wastes are usually complex mixtures (Harding and Whitton 1976; Vivian and Massie 1977). Hence, assemblages are not normally exposed to a single metal ion without other metals or nutrients. Similarly, a mixture of metals may exert different effects on a phytoplankton assemblage (assuming that the composition of the assemblage is identical or similar) because the different populations that comprise the community may not be growing optimally and some life cycle stages are more susceptible to toxicants (Rabsch and Elbrächter 1980).

The rationale for selecting phosphorus and silica as nutrient additions in our experiment was based on the fact that both of these nutrients most often limit phytoplankton growth in the Great Lakes. The assemblage was collected in September, long after spring turnover and the silica maximum in the water column. Both nutrients were added to obtain concentrations that can be found in the Great Lakes at other times of the year, yet they are nowhere near the levels found in culture medium.

The nature of the synergistic effects of nutrients and heavy metals on phytoplankton is not known with certainty. Morel et al. (1978) have speculated that one of the targets of copper in diatoms is silicon metabolism and they have reported a decrease in copper toxicity in the presence of high silica concentrations. Thomas et al. (1980b) found that silicon metabolism was adversely affected by copper, zinc, and germanium. Similarly, Sicko-Goad and Stoermer (1979) found that copper prevented the formation of polyphosphate bodies in a diatom and speculated that the target of copper toxicity was the phosphate uptake mechanism. Conway (1978) found that phosphate and silicate utilization by $A s^{-}$ terionella was initially enhanced in cells treated with cadmium. This enhancement was noted prior to the cessation of growth and he speculated that there was a breakdown in the phosphate and silicate permease transport systems. It is probably reasonable to suspect that cells that are nutrient sufficient (with respect to the above examples) would be less susceptible to the toxicity effects of the metals.

It is an impossible task to simulate the natural environment with any degree of reproducibility. It is also an impossible task to determine with absolute certainty the cause-effect relationships of metals on natural phytoplankton species. While selective inhibition of phytoplankton species in a natural assemblage may be detected by changes in community composition and structure (Jennings 1979; Mosser et al. 1972), it is difficult to separate species effects at sub-lethal doses. Wong and Beaver (1980) suggested that extra caution be taken in the interpretation of toxic threshold assays with natural populations due to algal interactions such as competition, extracellular products, and nutrient competition. We would extend this caution further, because environmental factors that may change the availability of metals may also change the physiological state of the cells, which may either amplify or mitigate the metal effect.

Acknowledgments. Supported by Grant R-807516010 from the Office of Exploratory Research, The United States Environmental Protection Agency. Contribution No. 440 of the Great Lakes Research Division.

\section{References}

Ahlf W, Irmer U, Weber A (1980) Uber die Anreicherung von Blei durch Suwassergrunalgen unter Berucksichtigung verschiedener Au enfaktoren. 2. Plfanzenphysiol 100:197-207

Allen HE, Hall RH, Brisben TD (1980) Metal speciation. Effects on aquatic toxicity. Environ Sci Technol 14:441-443

Baxter M, Jensen TE (1980a) A study of methods for in situ $\mathrm{X}$-ray energy dispersive analysis of polyphosphate bodies in Plectonema boryanum. Arch Microbiol 126:213-215

- (1980b) Uptake of magnesium, strontium, barium, and manganese by Plectonema boryanum. Protoplasma 104:8189

Canterford GS (1980) Formation and regeneration of abnormal cells of the marine diatom Ditylum brightwellii (West) Grunow. J Mar Biol Assn UK 60:243-253

Canterford GS, Canterford DR (1980) Toxicity of heavy metals to the marine diatom Ditylum brightwellii (West) Grunow: Correlation between toxicity and metal speciation. J Mar Biol Assn UK 60:227-242

Choie DD, Richter GW (1972) Lead poisoning: Rapid formation of intranuclear inclusions. Science 177:1194-1195

Conway HL (1978) Sorption of arsenic and cadmium and their effects on growth, micronutrient utilization, and photosynthetic pigment composition of Asterionella formosa. J Fish Res Board Can 35:286-294

Crist RH, Oberholser K, Shank N, Nguyen M (1981) Nature of 
bonding between metallic ions and algal cell walls. Environ Sci Technol 15:1212-1217

Daniel GF, Chamberlain AHL (1981) Copper immobilization of fouling diatoms. Bot Mar 24:229-243

Davies AG (1978) Pollution studies with marine plankton. Part II. Heavy metals. Adv Mar Biol 15:381-508

Davies CO, Simmons MS (1979) Water chemistry and phytoplankton field and laboratory procedures. Univ Michigan Great Lakes Res Div Spec Rep No 70, Ann Arbor MI

DeHoff RT, Rhines FN (eds) (1968) Quantitative Microscopy. McGraw-Hill, New York

Fujita M, Iwasaki K, Takabatake E (1977) Intracellular distribution of mercury in freshwater diatom, Synedra cells. Environ Res $14: 1-13$

Gadd GM, Griffiths AJ (1978) Microorganisms and heavy metal toxicity. Microbiol Ecol 4:303-317

Gipps JF, Coller BAW (1980) Effect of physical and culture conditions on uptake of cadmium by Chlorella pyrenoidosa. Aust J Mar Freshwater Res 31:747-755

- (1982) Effect of some nutrient cations on uptake of cadmium by Chlorella pyrenoidosa. Aust J Mar Freshwater Res 33:979-987

Hallas LE, Thayer JS, Cooney JJ (1982) Factors affecting the toxic effect of tin on estuarine microorganisms. Appl Environ Microbiol 44:193-197

Harding JPC, Whitton BA (1976) Resistance to zinc of Stigeoclonium tenue in the field and the laboratory. Br Phycol J $11: 417-426$

(1977) Environmental factors reducing the toxicity of zinc to Stigeoclonium tenue. Br Phycol J 12:17-21

Hollibaugh JT, Seibert DLR, Thomas WH (1980) A comparison of the acute toxicities of ten heavy metals to phytoplankton from Saanich Inlet, B.C., Canada. Estuar Coast Mar Sci 10:93-105

Jennings JR (1979) The effect of cadmium and lead on the growth of two species of marine phytoplankton with particular reference to the development of tolerance. J Plankton Res 1:121-136

Jensen TE, Baxter M, Rachlin JW, Jani V (1982) Uptake of heavy metals by Plectonema boryanum (Cyanophyceae) into cellular components, especially polyphosphate bodies: an $x$-ray energy dispersive study. Environ Pollut Ser A 27:119-127

Kamphake LJ, Hannah SA, Cohen JM (1967) Automated analysis for nitrate by hydrazine reduction. Water Res 1:205216

Koeppe DE, Miller RJ (1970) Lead effects on corn mitochondrial respiration. Science 167:1376-1378

Lazinsky D, Sicko-Goad L (1979) Paraformaldhyde-glutaraldehyde as a routine phytoplankton fixative. Micron 10:49-50.

Lorenz RJ (1977) Statistiche probleme bei der Bestimmung relativer volumenanteile mit dem Punktozählverfahren. Mikros $33: 148-157$

Luft JH (1961) Improvements in epoxy embedding methods. J Biophys Biochem Cytol 9:409-14

Monahan TJ (1973) Lead inhibition of Hormotila blennista (Chlorophyceae, Chlorococcales). Phycologia 12:247

Moore JF, Goyer RA (1974) Lead induced inclusion bodies: composition and probable role in lead metabolism. Environ Health Perspect 7:121-127

Morel NML, Rueter JG, Morel FMM (1978) Copper toxicity to Skeletonema costatum (Bacillariophyceae). J Phycol 14: $43-8$
Mortonson JA, Brooks AS (1980) Occurrence of a deep nitrate maximum in Lake Michigan. Can J Fish Aquatic Sci $37: 1025-1027$

Mosser JL, Fisher NS, Wurster CF (1972) Polychlorinated biphenyls and DDT alter species composition in mixed cultures of algae. Science 176:533-535

Rabsch U. Elbrächter M (1980) Cadmium and zinc uplake, growth, and primary production to Coscinodiscus granil cultures containing low levels of cells and dissolved organic carbon. Helgolander Meeresunters 33:79-88

Rachlin JW, Jensen TE. Baxter M, Jani V (1982) Utilization of morphometric analyses in evaluating response of $\mathrm{Plec}$ tonema boryanum (Cyanophyceae) to exposure of eight heavy metals. Arch Environ Contam Toxicol 11:323-333

- Warkentine B (1984) The toxicological response of the alga Anabaena flos-aquae (Cyanophyceae) to cadmium. Arch Environ Contam Toxicol 13:143-151

- (1985) Morphometric analysis of the response of Anabaena flos-aquae and Anabaena variabilis (Cyanophyceae) to selected concentrations of zinc. Arch Environ Contam Toxicol 14: $395-402$

Saboski EM (1977) Effects of mercury and tin on frustular ultrastructure of the marine diatom Nitzschia liebeihruti. Water Air Soil Pollut 8:461-466

Schelske CL, Feldt LE, Santiago MA, Stoermer EF (1972) Nutrient enrichment and its effect on phytoplankton production and species composition in Lake Superior, pp. 149-165. In Proc 15 th Conf Great Lakes Res, Internat Assoc Great Lakes Res, Ann Arbor, MI

- Stoermer EF, Gannon JE, Simmons MS (1976) Biological, chemical and physical relationships in the Straits of Mackinac. US Environmental Protection Agency Ecological Research Series EPA 600/3-76-095 Environmental Research Laboratory, Duluth MN

- Simmons MS (1980) Phytoplankton and physical-chemical conditions in selected rivers and the coastal zone of Lake Michigan, 1972. University of Michigan Great Lakes Res Div Publ No 19, 162 pp, Ann Arbor, MI

Sicko-Goad L (1982) A morphometric analysis of algal response to low dose, short-term heavy metal exposure. Protoplasma $110: 75-86$

- Stoermer EF (1979) A morphometric study of lead and copper effects on Diatoma tenue v. elongatum (Bacillariophyta). J. Phycol 15:316-321

- Ladewski BG (1977) A morphometric method for correcting phytoplankton cell volume estimates. Protoplasma 93:147-63

Silverberg BA (1976) Cadmium-induced ultrastructural changes in mitochondria of freshwater green algae. Phycologia 15:155-9

Skaar H, Ophus E, Gullvag BL (1973) Lead accumulation within nuclei of moss leaf cells. Nature (London) 241:215-216

Smith MA (1983) The effect of heavy metals on the cytoplasmic fine structure of Skeletonema cosiatum (Bacillariophyta). Protoplasma 116:14-23.

Stuve J, Galle P (1970) Role of mitochondria in the handing of gold by the kidney. J Cell Biol 44:667-702

Thomas WH, Hollibaugh JT, Seibert DL 1980a. Effects of heavy metals on the morphology of some marine phytoplankton. Phycologia 19:202-209

Wallace GT Jr (1980b) Toxicity of a mixture of ten metals to phytoplankton. Mar Ecol Prog Ser 2:213-220 
Underwood EE (1970) Quantitative Stereology, AddisonWesley, Reading MA $274 \mathrm{pp}$

Vivian CM, Massie LS (1977) Trace metals in waters and sediments of the River Tawe, South Wales, in relation to local sources. Environ Pollut 14:47-61

Watson ML (1958) Staining tissue sections for electron micros- copy with heavy metals. J Biophys Biochem Cytol 4:475478

Wong SL, Beaver JL (1980) Algal bioassays to determine toxicity of metal mixtures. Hydrobiol 74:199-208

Manuscript received October 21,1985 and in revised form December $28,1985$. 